\title{
Tocilizumab for massive refractory pleural effusion in an adolescent with systemic lupus erythematosus
}

\author{
Arianna De Matteis, Emanuela Sacco, Camilla Celani, Andrea Uva, Virginia Messia, Rebecca Nicolai, \\ Manuela Pardeo, Fabrizio De Benedetti ${ }^{*}$ and Claudia Bracaglia
}

\begin{abstract}
Background: Pleural effusion in systemic lupus erythematous (SLE) is a common symptom, and recent studies demonstrated that IL-6 has a pivotal role in its pathogenesis.

Case presentation: We report a case of a 15 years old Caucasian boy with a history of persistent pleural effusion without lung involvement or fever. Microbiological and neoplastic aetiologies were previously excluded. Based on the presence of pleuritis, malar rash, reduction of C3 and C4 levels and positivity of antinuclear antibody (ANA) and anti-double stranded DNA (dsDNA), the diagnosis of juvenile SLE (JSLE) was performed. Treatment with high dose of intravenous glucocorticoids and mycophenolate mofetil was started with partial improvement of pleural effusion. Based on this and on adults SLE cases with serositis previously reported, therapy with intravenous tocilizumab (800 mg every two weeks) was started with prompt recovery of pleural effusion.
\end{abstract}

Conclusion: To the best of our knowledge, this is the first case of JSLE pleuritis successfully treated with tocilizumab.

Keywords: JSLE (Juvenile-onset Systemic Lupus Erythematosus) - Pleural effusion, IL-6, Tocilizumab

\section{Introduction}

Pleural effusion in systemic lupus erythematosus (SLE) occurs in $50 \%$ of the patients. It is usually bilateral, small in size, asymptomatic and responsive to low dose glucocorticoid [1,2]. We describe a patient with juvenile onset-SLE (JSLE) and massive refractory pleural effusion treated with tocilizumab (TCZ). Two cases of adult SLE patients with pleuritis successfully treated with TCZ have been reported [2, 3]. Interleukin-6 (IL-6) is a potential target in SLE given its role in anti-double stranded DNA (dsDNA) production and in the autocrine hyperactivity of B cells with spontaneous secretion of a large IL-6 amount and constitutive IL-6R expression [4-6].

\footnotetext{
* Correspondence: fabrizio.debenedetti@opbg.net

Division of Rheumatology, ERN RITA center, IRCCS Ospedale Pediatrico Bambino Gesù, Piazza Sant'Onofrio, 4-00165 Rome, Italy
}

\section{Case report}

A previously healthy 15 -years-old Caucasian boy developed progressive dyspnoea and asthenia. At onset, laboratory features showed leukopenia $\left(2.38 \times 10^{3} / \mathrm{uL}\right)$, lymphopenia $\left(0.89 \times 10^{3} / \mathrm{uL}\right)$, hypergammaglobulinemia $(22.31 \mathrm{~g} / \mathrm{l})$ and normal C-reactive protein (CRP) $(<$ $0.5 \mathrm{mg} / \mathrm{dl})$; antinuclear antibody (ANA) and anti-dsDNA were negative. Lung computed tomography (CT) demonstrates the presence of left pleural and pericardial effusion, without lung involvement and elevated hemidiaphragm (Fig. 1, panel A). He was treated with multiple antibiotics, with no response, and underwent four thoracenteses, with no microbial isolate. After two months, he was admitted to our division for the persistence of pleural effusion. He presented in poor general condition with tachypnoea, respiratory distress, requiring

C C The Author(s). 2021 Open Access This article is licensed under a Creative Commons Attribution 4.0 International License, which permits use, sharing, adaptation, distribution and reproduction in any medium or format, as long as you give appropriate credit to the original author(s) and the source, provide a link to the Creative Commons licence, and indicate if changes were made. The images or other third party material in this article are included in the article's Creative Commons licence, unless indicated otherwise in a credit line to the material. If material is not included in the article's Creative Commons licence and your intended use is not permitted by statutory regulation or exceeds the permitted use, you will need to obtain permission directly from the copyright holder. To view a copy of this licence, visit http://creativecommons.org/licenses/by/4.0/ The Creative Commons Public Domain Dedication waiver (http://creativecommons.org/publicdomain/zero/1.0/) applies to the data made available in this article, unless otherwise stated in a credit line to the data. 


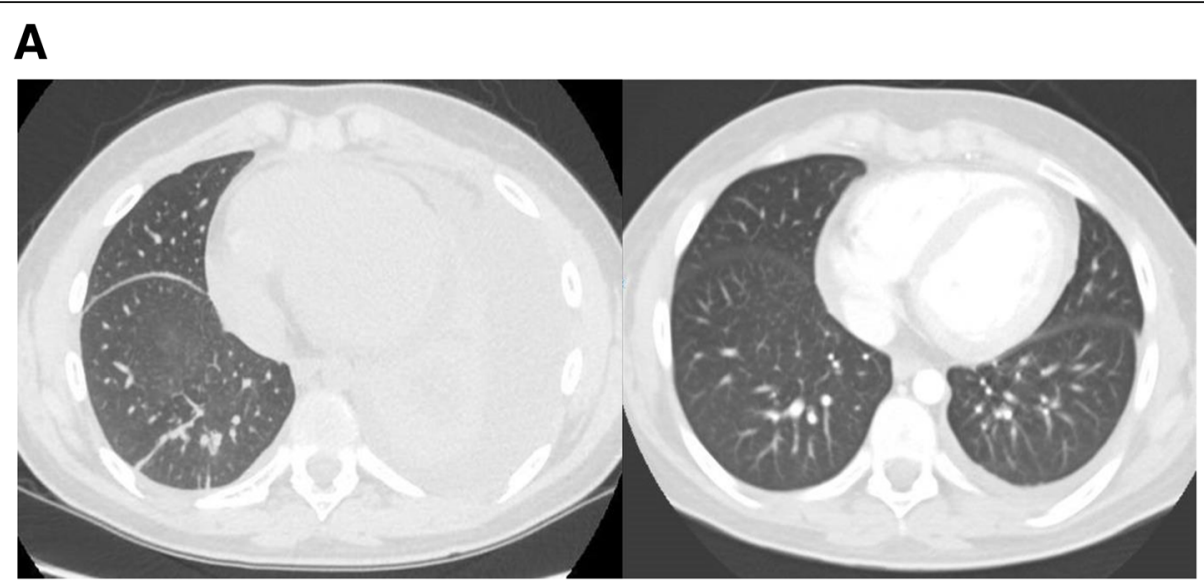

B

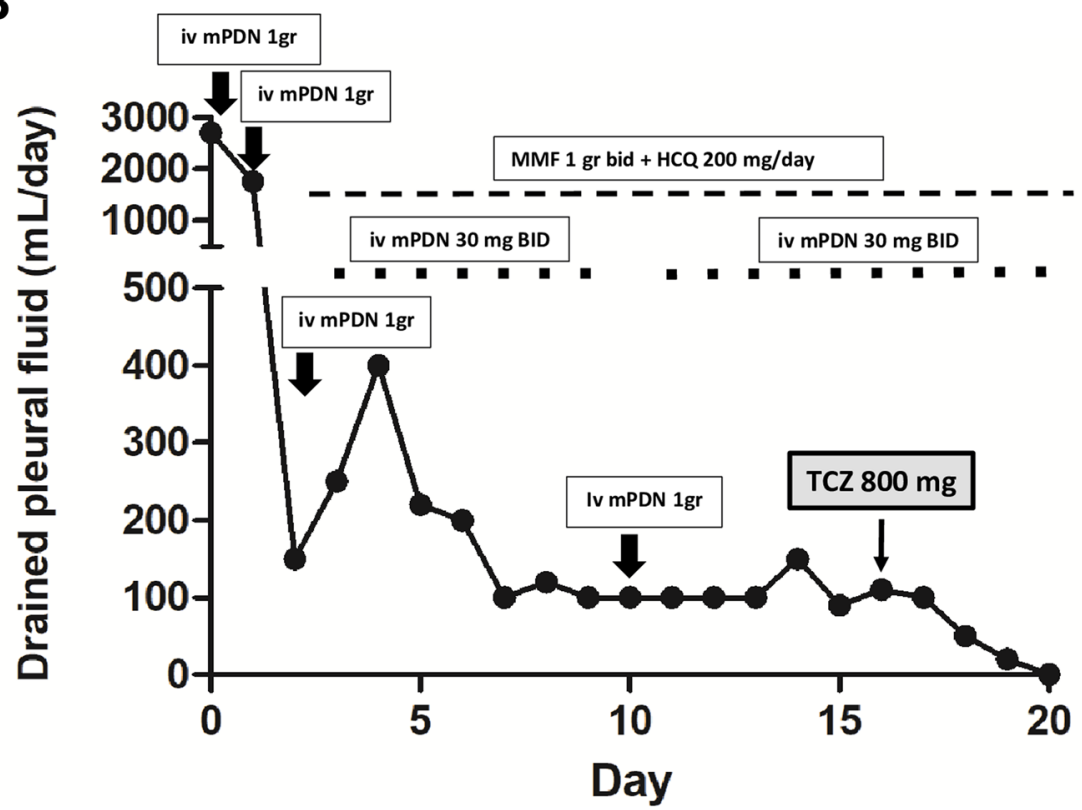

Fig. 1 a Lung computed tomography (CT) before treatment with glucocorticoids and subsequent tocilizumab (left) and after (right) 9 days from the first dose of tocilizumab. $\mathbf{b}$ volume of drained pleural fluid and therapies administered. Arrows indicated $1 \mathrm{gr}$ mPDN iv pulses. BID: twice a day

$\mathrm{O}_{2}$ supplementation, dullness over the left lung and mild malar rash. CRP, blood cell count, liver and kidney functional tests and urine analysis were normal. $\mathrm{C} 3$ and $\mathrm{C} 4$ levels were low. ANA, anti-dsDNA, anti-Sm and antiU1RNP antibodies were present (Table 1). Type I interferon (IFN) signature was markedly elevated (score 76.4 median fold change). A massive left pleural effusion was was drained $(2800 \mathrm{ml})$ and chest tube placed with marked improvement. Renal, cardiovascular and central nervous system involvement was excluded. A diagnosis of SLE was made according to the 2012 SLICC and 2019 EULAR/ACR criteria. Methylprednisolone (mPDN) pulses ( $1 \mathrm{gr} /$ day, equal to $15 \mathrm{mg} / \mathrm{kg} /$ day, for 3 consecutive days) followed by $\mathrm{mPDN} 60 \mathrm{mg} /$ day (equal to $0.8 \mathrm{mg} / \mathrm{kg} /$ day) were administered. Simultaneously mycophenolate mofetil (MMF) (1000 mg, equal to $600 \mathrm{mg} /$ $\mathrm{m} 2$, twice a day) and hydroxychloroquine (HCQ) (200 $\mathrm{mg} /$ day, equal to $3 \mathrm{mg} / \mathrm{kg}$ ) were also added. The daily volume of drained fluid mildly decreased (Fig. 1, panel $\mathrm{B}$ ), and 10 days after one additional mPDN pulse was administered with no substantial effect. After 2 weeks, intravenous TCZ (800 mg, equal to $12 \mathrm{mg} / \mathrm{kg}$, every two weeks) was started. Driven by the need for a rapid response before moving to other untargeted immunochemotherapies or invasive approaches (pleurodesis), we chose to use a high dose of TCZ to avoid the risk of under dosing. Immediately after the first dose, the daily volume of drained fluid decreased progressively allowing to remove the chest tube drainage on day +4 after the first TCZ dose (Fig. 1, panel B). Nine days after the first TCZ dose, a chest CT documented no pleural effusion (Fig. 1, panel A). Prednisone (PDN) was 
Table 1 Laboratory parameters before treatment with tocilizumab (TCZ), after 6 months and after 12 months from starting TCZ (WBC = White blood cell count; $\mathrm{N}=$ Neutrophils; $\mathrm{L}=$ Lymphocyte count; $\mathrm{Hb}=$ Hemoglobin; $\mathrm{PLT}$ = platelet count; $\mathrm{CRP}=\mathrm{C}$ reactive protein; SLEDAI = Systemic Lupus Erythematosus disease activity index); NA = not available.

\begin{tabular}{|c|c|c|c|c|c|c|}
\hline & Baseline & $72 \mathrm{~h}$ after TCZ & 1 month after TCZ & 6 months after TCZ & 12 months after TCZ & Normal value \\
\hline WBC $\left(x 10^{9} / L\right)$ & 4.0 & 9.91 & 5.4 & 4.2 & 4.4 & $4.0-13.5$ \\
\hline$N\left(x 10^{9} / L\right)$ & 2.0 & 5.41 & 2.4 & 1.42 & 1.7 & $1.3-7.9$ \\
\hline$L\left(x 10^{9} / L\right)$ & 1.5 & 3.73 & 2.5 & 2.2 & 2.25 & $1.0-6.5$ \\
\hline $\mathrm{Hb}(\mathrm{g} / \mathrm{dL})$ & 11.2 & 12.5 & 13.7 & 12.5 & 12.9 & $13.0-16.0$ \\
\hline PLT (x10\%/L) & 259 & 219 & 109 & 208 & 191 & $150-450$ \\
\hline CRP (mg/dL) & 0.6 & $<0.03$ & 0.03 & 0.03 & 0.03 & $<0.5$ \\
\hline $\lg G(g / L)$ & 22.31 & & 8.09 & 6.16 & 6.98 & $5.50-15.80$ \\
\hline C3 (g/L) & 0.36 & 0.57 & 0.71 & 0.67 & 0.75 & $0.90-1.80$ \\
\hline C4 (g/L) & 0.02 & 0.03 & 0.05 & 0.07 & 0.14 & $0.10-0.40$ \\
\hline Anti-dsDNA antibody score titer & $1: 640$ & NA & $1: 20$ & 1:10 & $1: 10$ & $<1: 10$ \\
\hline Anti-Sm antibody $(\mathrm{U} / \mathrm{mL})$ & 14480.0 & NA & 1589.0 & 496.0 & 428.0 & $<5.0$ \\
\hline Anti-U1RNP IgG antibody (U/mL) & 370.0 & NA & 245 & 145.0 & 111.0 & $<7.0$ \\
\hline SLEDAI & 14 & 6 & 2 & 2 & 2 & $\leq 4$ \\
\hline
\end{tabular}

progressively tapered without flares to $7,5 \mathrm{mg} /$ day $(0.09 \mathrm{mg} / \mathrm{kg} /$ day $)$ at 9 months. After 6 months of treatment, blood tests improved (Table 1) and the infusioninterval of TCZ was extended to every 3 weeks without flares. After one year, the patient was in good clinical condition, still on TCZ (12 $\mathrm{mg} / \mathrm{kg}$ every 3 weeks), oral PDN (5 mg/day, equal to $0.06 \mathrm{mg} / \mathrm{kg} /$ day), MMF (1 gr twice/day) and HCQ (200 mg/day). Pleural and pericardial effusions were not detected. Clinical inactive disease was maintained (SLEDAI 2), C3 and C4 improved but $\mathrm{C} 3$ of $0.75 \mathrm{~g} / \mathrm{l}$ remained below the normal range (Table 1).

\section{Discussion and conclusion}

Lupus pleuritis is caused by immune complex deposition, complement activation and direct binding of antidsDNA antibodies to mesothelium [7]. Several data suggest that IL-6 plays a critical role in B-cell hyperactivity and immunopathology of SLE and that it may have a direct role in mediating tissue damage [4]. A pilot study on 16 SLE patients and a trial on 15 SLE patients treated with TCZ showed a significant improvement in disease activity, and a significant reduction of levels of IgG and of anti-dsDNA $[4,5]$. The trial also demonstrated that TCZ treatment significantly decreased the frequency of plasma cells and activated $\mathrm{T}$ cells, leading to a shift to a naïve $\mathrm{B}$ and $\mathrm{T}$ cells phenotype [4]. TCZ is not a standard treatment for SLE pleural effusion, with only two cases of adult patients reported [2, 3]. We chose TCZ because of its targeted mechanism, making it more selective, less immunosuppressive and with less potential short-term and long-term side effects compared to other conventional immunochemotherapy or pleurodesis.
Most likely, a combined effect of GCS, MMF and TCZ completely controlled pleural effusion, rapidly leading to inactive disease. However persistent mild low levels of C3 were observed. This may be due to neutralization of IL-6 activities, as reported in rheumatoid arthritis [8], rather than being a sign of disease activity, due to decreased liver production and not to consumption. Since a standardized protocol for the administration of TCZ in lupus patients is not available, the chosen regimen was based on the previous TCZ trials in SLE $[4,5]$. Dosing regimen, timing of tapering and discontinuation of the drug are not defined and should be based on patient clinical condition.

\section{Abbreviations}

ANA: antinuclear antibody; Anti ds-DNA: double stranded DNA; anti-Sm: antiSmith; CRP: C-reactive protein; CT: computed tomography;

HCQ: hydroxychloroquine; IL-6: interleukin-6; IL-6R: interleukin-6 receptor;

JSLE: juvenile onset-SLE; MMF: mycophenolate mofetil;

mPDN: methylprednisolone; PDN: prednisone; SLE: systemic lupus

erythematous; SLEDAl: Systemic Lupus Erythematosus Disease Activity Index; TCZ: tocilizumab

\section{Acknowledgements}

Not applicable.

Authors' contributions

ADM collected data, drafted the work and approved the submitted version. $E S, C C, A U, V M, R N, M P$ revised the work and approved the submitted version. FDB and $C B$ drafted and revised the work.

\section{Funding}

None.

Availability of data and materials Not applicable.

\section{Declarations}

Ethical approval and consent to participate Not applicable. 


\section{Consent for publication}

A written consent form for pubblication of data was obtained by parents.

\section{Competing interest}

Dr. De Benedetti has received unrestricted research support paid to his institution from AbbVie, Hoffmann-La Roche, Pfizer, Novlmmune, Novartis, Sobi and Sanofi.

Received: 24 June 2021 Accepted: 30 August 2021

Published online: 16 September 2021

\section{References}

1. Midgley A, Watson L, Beresford MW. New insights into the pathogenesis and management of lupus in children. Arch Dis Child. 2014;99:563-7.

2. Ocampo V, Haaland D, Legault K, Mittoo S, Aitken E. Successful treatment of recurrent pleural and pericardial effusions with tocilizumab in a patient with systemic lupus erythematous. BMJ Case Rep. 2016;2016:bcr2016215423.

3. Kamata $Y$, Minota S. Successful treatment of massive intractable pericardial effusion in a patient with systemic lupus erythematosus with tocilizumab. BMJ Case Rep. 2012;2012:bcr2012007834.

4. Shirota Y, Yarboro C, Fischer R, Pham TH, Lipsky P, Illei GG. Impact of antiinterleukin-6 receptor blockade on circulating $T$ and $B$ cell subsets in patients with systemic lupus erythematosus. Ann Rheum Dis. 2013;72:118-28.

5. Illei GG, Shirota Y, Yarboro CH, Daruwalla J, Tackey E, Takada K, et al. Tocilizumab in systemic lupus erythematosus: data on safety, preliminary efficacy, and impact on circulating plasma cells from an open-label phase I dosage-escalation study. Arthritis Rheum. 2010;62:542-52.

6. Choy EH, De Benedetti F, Takeuchi T, Hashizume M, John MR, Kishimoto T. Translating IL-6 biology into effective treatments. Nat Rev Rheumatol. 2020; 16:335-45.

7. Man BL, Mok CC. Serositis related to systemic lupus erythematosus: prevalence and outcome. Lupus. 2005;14:822-6.

8. Romano C, Del Mastro A, Sellitto A, Solaro E, Esposito S, Cuomo G. Tocilizumab reduces complement $\mathrm{C} 3$ and $\mathrm{C} 4$ serum levels in rheumatoid arthritis patients. Clin Rheumatol. 2018 Jun;37:1695-700.

\section{Publisher's Note}

Springer Nature remains neutral with regard to jurisdictional claims in published maps and institutional affiliations.

Ready to submit your research? Choose BMC and benefit from:

- fast, convenient online submission

- thorough peer review by experienced researchers in your field

- rapid publication on acceptance

- support for research data, including large and complex data types

- gold Open Access which fosters wider collaboration and increased citations

- maximum visibility for your research: over $100 \mathrm{M}$ website views per year

At $\mathrm{BMC}$, research is always in progress.

Learn more biomedcentral.com/submissions 